\title{
THE IMPLEMENTATION OF TASK-BASED INSTRUCTION IN TEACHING SPEAKING
}

\author{
Mutiara Stepani \\ Indonesia University of Education, Bandung, Indonesia \\ E-mail: mutiarastepani@gmail.com
}

APA Citation: Stepani, M. (2016). The implementation of task-based instruction in teaching speaking. Indonesian EFL Journal, 2(1), 43-52

Published: 01-01-2016

Abstract: This study aims at investigating the benefits and challenges encountered by the teacher and the students in implementing task-based instruction. This study mainly utilizes a qualitative research design covering the trait of a case study. This study was carried out in one vocational high school in Bandung involving one class from the eleventh grade students. The data were collected through interview and questionnaires. The data from classroom interview and questionnaires were analyzed qualitatively. The result of interview and questionnaires revealed that task-based instruction resulted in some benefits and challenges. It was revealed that task-based instruction contributes to students' speaking skill and enhances students' participation. Apart from those benefits, some challenges were also found in terms of teacher's competence, availability of time, and mixed ability students. Accordingly, it is recommended that this method is implemented in a long period of time.

Keywords: task-based instruction, teaching speaking, benefits of task-based instruction, challenges of task-based instruction

\section{INTRODUCTION}

Speaking English is considered as the most fundamental skill to be mastered in language learning (Aleksandrzak, 2011; Bashir, Azeem, \& Dogar, 2011; Hasan, 2014; Malihah, 2010; Oradee, 2012). It is supported by the fact that speaking proficiency is often used as the measurement of the success of learners in learning English (Richards, 2008). In Indonesian context, speaking skill is considered as an important skill to be mastered by senior high-school students, either public high school or vocational high school.

However, speaking is considered as a difficult skill to develop. It is because of the students' lack of exposures, lack of confidence, and lack of motivation (Febriyanti, 2011). Speaking skill is also considered challenging because the students need more time and courage to speak (Bashir et al., 2011; Oradee, 2012).
In addition, some of the students are reluctant to speak because they feel nervous in expressing themselves in front of other people (Harmer, 2007).

Based on preliminary observation, some problems of speaking are also found in a vocational school in Cimahi. The observation showed that many students were reluctant to speak and looked nervous to speak in English. Some of the students did not want to raise hands to answer teacher's questions. The preliminary observation also showed that the students need more hours to practice speaking because they are trained to be ready to work in companies and demanded to speak communicatively. Hence, it is noteworthy for organizing instruction, which can accommodate the demands of curriculum and the students' needs. In other words, it is prominent in 


\section{Mutiara Stepani}

The Implementation of Task-Based Instruction in Teaching Speaking

having a teaching-learning process which encourages the students to speak English. In accord with a decree of the Minister of Education and Culture No 70/2013, the teaching-learning process requires the instruction which focuses on learner-centered and interaction, involves students as active participants, provides students to work collaboratively in groups, and uses multimedia as the teaching media. In relation to speaking skill issue, the English teacher in this study is required to give instruction which encourages the students to be actively engaged in doing tasks either individual or collaborative tasks by using a target language.

Task-based instruction, hence it will be mentioned as TBI, is the alternative method which can fulfill the aforementioned expectation. Task-based instruction is defined as an instruction which promotes learner centeredness (Ellis, 2003; Nunan, 2004; Richards \& Rodgers, 2001), and uses tasks as the center of instruction and language to complete the tasks (Kumaravadivelu, 2012; Littlewood, 2007; Schmidt, Platt, \& Schmidt, 2003 as cited in Shehadeh \& Coombe, 2010).

TBI lesson in the classroom goes through different sequencing frameworks proposed by some researchers (Ellis, 2003; Prabhu, 1987; Skehan, 1996; Willis, 1996). They have three principal phases which reflect the chronology of a taskbased lesson. Ellis (2003) describes TBI sequences into pre-task, during-task, and post-task. Willis (1996) proposed three sequencing stages involving a pre-task, the task, and language focus.

The first stage of TBI is the pre-task stage. This stage takes place at the beginning of the lesson to prepare various activities before starting the task (Aliakbari \& Jamalvandi, 2012). Willis (1996) proposes three steps of pre-task stage. First, the teacher has to introduce the topic by defining the topic area.
Second, the teacher identifies the topic language i.e. assisting the students to introduce, recall, or activate the vocabularies, words, or phrases that will be used during the task. Third, the teacher ensures that students understand what to do and what to achieve in the task.

The second stage of TBI is a task cycle. The task phase allows students to show their effort to achieve the goal (Beretta \& Davies, 1985). This phase allows them to work together to communicate and carry out the meaningful activity which concentrates on fluency and producing forms of language (Hyde, 2013). Willis (1996) proposes three components of a task cycle; the task, planning, and report.

The third stage presents the language analysis and practice stage which focusing on language form and use (Ellis, 2003; Willis, 1996). This stage consists of two activities; the language analysis and language practice activities. The Language analysis activities called as consciousness-raising activities or language awareness activities. These activities provide the students by identifying the language features from the task stage by giving the explicit instruction of teaching form or grammar (Branden, 2006; Ellis, 2003; Nunan, 2004). On the other hand, the language practice activities are conducted to increase learners' confidence and help them to improve their fluency in using language features (Ellis, 2003; Nunan, 2004). At this stage, the teacher presents activities to practice the language that the students have analyzed in the previous activity that can be spoken, or mainly written.

Further, a number of studies have examined the implementation of TBI on students' speaking skill in the EFL context. The research in the Turkish context showed that TBI develops students' speaking and engages 
meaningful interaction among the students (Kırkgöz, 2011). Additionally, TBI also had beneficial effects on students' learning process, enhances the interaction among students, gives the students opportunity to practice target language, and gives a relaxed atmosphere with enjoyable activities (Ismaili, 2013). In Thai context, Uraiwan (2010) found that TBI helps the students improving their English-speaking and gives positive opinions such as learning with TBI was fun, interesting, and relevant to realworld language. In China, Xiongyong and Samuel (2011) explored the implementation of task-based language teaching among 132 secondary schools EFL teachers in China, it showed that most of the teachers had positive attitudes toward TBI execution, but many teachers did not employ TBI. Further, in Korea, Yim (2009, cited in Wichitwarit, 2014) revealed that TBI could increase class participation, students had greater confidence in speaking English, and they have positive attitudes towards learning English.

The problem of the study was further supported by the results of previous related studies in the Indonesian context. Gunawan (2013) conducted a study in university level in order to seek how a task-based instruction affects the students' speaking skill. The results showed that there is significant improvement in students' speaking skill after learning by using task-based instruction. Further, Rohani (2012) conducted a research on the implementation of TBI to tertiary English language class. The results showed positive responses towards TBI, which is indicated by the increase of students' self-esteem, risk-taking behavior, and motivation to learn English. Besides, the students also showed improvement in using strategic competence in oral communication skills.

The aforementioned research has explored task-based instruction and responses towards TBI. Few were known regarding how the teacher implements task-based instruction in classroom practice, particularly in vocational high school level. Therefore, this study is concerned with seeking the benefits and challenges of task-based instruction to teach speaking at a vocational high school level.

\section{METHOD}

This study focuses on revealing the benefits and challenges of Task-Based Instruction in teaching speaking encountered by the teacher and the students. The study employs a case study to gain an in-depth understanding concerning particular events, a program, a process, and activity which was focused on teaching-learning process (see Creswell, 2008; Merriam, 1991).

The study was undertaken at a vocational high school in Cimahi, West Java. There were two reasons in selecting this research site. First, the English teacher had the same interest in promoting the use of TBI in his classroom, and he had been conducting research on various aspects related to TBI. He also implemented TBI in his teaching-learning process. Thereby, it is assumed that the English teacher might have knowledge of TBI and its theoretical foundations. Hence, it is expected that this research is contributed to develop the teacher's way in teaching speaking using Task-Based Instruction (TBI). Second, the researcher has access to the site. The data collection techniques employed in this study were observation, teacher's interviews, and questionnaires.

Interview was conducted to gather the data regarding the benefits and challenges of the implementation of TBI. A semi-structured interview with openended questions was employed in interviewing the respondent. There were some steps of analyzing the interview data, such as transcribing, coding, categorizing, and interpreting the data 
from interview to address research questions. Relevant theories were also used to justify the data. Then, the questionnaire was administered to the students in order to answer the research question. In this study, a set of openended questionnaires were used. The questionnaires proposed by Gunawan (2013) were applied to support data from interview.

\section{RESULTS AND DISCUSSIONS}

This section discusses the findings obtained from interview and observation. From the analysis, it was revealed that the implementation of Task-Based Instruction in teaching speaking gives some benefits and challenges.

\section{The Benefits of the Implementation of Task-Based Instruction in Teaching Speaking}

The result of the analysis showed that there are two benefits of the implementation of Task-Based Instruction. Firstly, TBI contributes to students' speaking skill. Secondly, TBI contributes to students' participation in the classroom.

\section{a. Task-Based Instruction contributes to the students' speaking skill}

On the basis questionnaires and interview, it was found that TBI contributes to students' speaking skill. It was reflected on the questionnaires data which showed that most of the students feel that Task-Based Instruction activities contribute to their speaking skill. 33 out of 35 students stated that their speaking skill was developed through TBI. The students' responses on the questionnaire are described in the following excerpt.

\footnotetext{
Excerpt \#1

"Bertambah sedikit demi sedikit karena setiap pertemuan guru memberikan pengetahuan baru kepada siswa tentang grammar dan vocabulary" (S3)
}

([My speaking skill] was getting better because the teacher always gave us new materials about grammatical form and vocabulary in every meeting)

\section{Excerpt \#2}

"Meningkat seiring dengan kosakata saya yang bertambah" (S2)

([My speaking skill] improves along with the improvement of my vocabulary mastery)

Excerpt \#1 illustrates that the student's speaking skill developed because of grammatical form and vocabularies taught by the teacher. While, Excerpt \#3 illustrates that TaskBased Instruction also enhanced his vocabulary mastery. In this context, the students not only practice how to speak by using target language but also how to communicate with it.

Based on the teacher's interview, the students are paying attention to their accuracy while performing dialog and stating the expressions orally without any hesitant after implementing TBI. Consequently, after several meetings, TBI encourages them to speak and communicate actively. This finding also was depicted in the data of the teacher's interview which highlighted the students' speaking improvement as follows.

\footnotetext{
First, in terms of... err... students' skill, it's so great. Significantly developed! It means that students' speaking skills after implementing TBI are developed as expected by target task. The students can deliver the message and feel unafraid in stating the expressions. That's the point, when they felt unafraid in communicating. Unafraid here means they don't show any hesitant in speaking. Therefore, they might think that communication in English is important. In addition, as we know that in communicating, we have to know other factor such as they are scared of making mistakes or afraid of mispronouncing the words. However, those factors are not quite
} 
important for me. As long as they can deliver the message, that's great! (Teacher interview)

The examples of the teacher's remark above indicated that the activities in Task-Based Instruction implementation influenced students' speaking skills. It was because the activities in TBI encourage the students to speak actively, give the students opportunity to learn pronunciation, vocabulary, and grammar, encourage the students to work independently, and encourage them to interact in English. Thus, the activities seemed motivating the students in learning. Those findings are in line with the statement that TBI can support the development of students' target language, give positive attitudes of learning to speak, help the students to increase their motivation to speak, and increase students' ability to speak fluently and correctly (Lochana \& Deb, 2006; Ruso, 2007; Willis, 1996).

\section{b. Task-Based Instruction Enhances Students' Participation in Teaching Learning}

The interview results revealed that activities done in every meeting make the students negotiate meaning by themselves and become independent learners. Those impacts can be found mostly in the task-cycle when they interact and work in groups or in pairs. Regarding this, the following excerpt shows this assumption.

R : How about students' involvement? Is there any difference after implementing TBI?

$\mathrm{T}$ : Honestly, $50 \%$ of students involved actively after implementing TBI. Many things have changed. At least, it is a good progress for the vocational students. Before implementing TBI, the students kept silent or sometimes they seemed afraid and shy when I asked them to practice or answer questions. However, this $50 \%$ of the students are able to ask questions or practice speaking in front of the class. Besides, this percentage is the maximum result of my effort. Now I know that there is connection between a method used and the goal of the task stages. Clear stages help them realize how to do the task. Like in the second stage, the students just explore the language. The important thing is the students do know that I never blame their mistakes unless giving motivation.

(Int\#1, 30/09/15)

Moreover, regarding students' participation, it can be seen from the students' questionnaires result. It was found that $71 \%$ of the students stated that they were very active in Task-Based Instruction lesson while 29\% stated that they were quite active in answering the questions. It was also confirmed by the statements wrote by the students below.

Sangat aktif seperti dalam memberikan pendapat, menjawab pertanyaan, dan berdialog di depan kelas (S12) ([I am] very active in giving opinion, answering questions, and performing dialog in front of the class)

Saya terlibat secara aktif dalam menjawab pertanyaan, berpendapat serta berani menampilkan bahasa inggris saya melalui dialog (S6)

(I am involved actively in answering questions, stating opinion, and performing my english skill through dialog)

\section{Aktif dalam menjawab dan bekerja kelompok (S7)}

(Actively answer and do the task in pair or group)

Those excerpts support the studies which suggest that Task-Based Instruction increases students' motivation and encourages them to be the risk takers (Torky, 2006).

\section{The Challenges of the Implementation of Task-Based Instruction in Teaching Speaking}

In implementing the Task-Based Instruction, there were three main challenges that could hinder the effectiveness in gaining its benefits. The challenges had something to do with teacher's competence, availability of time, 
and mixed ability students' proficiency as depicted in the following sections.

\section{a. Teacher's Competence}

Based on the interview, the challenges during the implementation of Task-Based Instruction were related to teacher's preparation and teacher's roles in encouraging students to communicate in target language. Regarding the teacher's preparation, the teacher argued that he should be well-prepared in implementing Task-Based Instruction, including the materials, contexts, strategy of teaching, and media based on the students' characters in the classroom. It is shown in the interview below.

$\mathrm{R}$ : Is there any challenge you faced when implementing TBI in your classroom?

$\mathrm{T}$ : I have to be well-prepared; especially selecting appropriate strategy and media for selected basic content. I have to prepare to implement TBI because the reality is somehow different from the theory itself. To implement this method, it is important to know the contexts, materials, students, and class environments. How TBI is carried out in the classroom is such a challenging task. Like what I did today, I combined procedure and strategy to overcome my difficulties. Then, it is also challenging for the teacher to introduce the topic which makes them communicate in target language. Teacher plays as an important role. That's why I said before that well-prepared teacher is important. Well prepared here belongs to various aspects such giving various materials, using media such as video, power point, and questions and answers strategy.

(Int\#1, 30/09/15)

Additionally, the teacher's competence in designing an effective lesson plan, delivering the lesson, and managing the classroom was essential. During observation, the teacher used different kinds of media such as video and power point. At the other time, the teacher asked the students to engage in the discussion. Those strategies and media bring new things to students and might encourage students' enthusiasm in learning.

Concerning the challenge above, Gebhard (2009) stated that the teacher needed lots of time and effort to prepare authentic materials and media. However, it also has benefits as a way to reinforce the students in connecting language in the classroom to the real world outside the classroom. Besides, it is supported by Richards (2001) who states that authentic materials such as video, text, and photographs provide supports to learn a language in a natural way. Therefore, the teacher should be able to organize teaching activities which could accommodate all students in achieving target tasks.

\section{b. Availability of Time}

The second challenge found in the implementation of Task-Based Instruction was the time of learning. 28.5 $\%$ or 10 out of 35 students stated that they have lack of time in accomplishing the tasks in Task-Based Instruction. Some students wrote the following statements on their questionnaires.

\section{TBI membutuhkan waktu lebih banyak (S1)} (TBI needs lots of time)

Butuh waktu lama dalam memahami materi (S31)

(Need more time to understand the materials)

Kurangnya waktu membahas grammar dan vocabulary (S13)

(Lack of time in explaining grammar and vocabulary)

In Indonesian vocational school, the time of learning English for eleventh grade of students is $1 \times 45$ minutes in a week. This time allocation was considered less to have students master the speaking skill. This limited time of learning also influenced students' language learning, such as grammar and vocabulary. Based on the questionnaire above, it was found that the student 
seemed need more time in understanding grammar and memorizing vocabularies. The reason might because they were used to learn English which focused on word formation, spelling, and vocabulary (Alwasilah, 2001). Therefore, due to limited of time, this teaching program focused on encouraging students to communicate. As stated by the teacher in the interview script below.

Grammar is important to teach implicitly, not explicitly. Therefore, there was no grammar focus at the beginning of the lesson. Not form focus. It means that the students can explore the expression or understand the meaning in communication. That's good. In the last stage, I explain grammatical form. We discussed about what they had said in the dialog. For example, in the dialog the students made grammatical error, so I could explain the right sentence at this stage. Grammar is important, but if we talk about TBI, communication first, grammar later. The portion is $25 \%$ grammar and $75 \%$ communication. Grammar is only for correcting the language produced by the students.

(Teacher interview)

As a consequence, the students with better language form were able to follow the instruction. It was because they could comprehend the instruction better. Thus, this challenge should be taken into account for the teacher in managing tasks with better proportion of time.

\section{c. Mixed proficiency level}

The last challenge in this study dealt with students' proficient level. $22.8 \%$ or 8 students admitted that they have lack of language proficiency such as limited vocabularies, grammar, and pronunciation. Those challenges were their obstacles in understanding the instructions and in expressing their opinion.

Guru selalu menggunakan bahasa inggris saat menjelaskan sehingga membuat saya kurang paham (S30)

(The teacher always uses English in explaining the materials so that I don't really understand about it)
Membosankan karena tidak bisa menjawab pertanyaan yang diberikan (S8)

(It bored me because I couldn't answer the question given by the teacher)

In consequence, there were some students who used Bahasa Indonesia while answering teacher's questions or discussing in groups. This is considered as the consequence of students' lack of language proficiency. It is in line with the statement that Task-Based Instruction gives chances to students in using their mother tongue (Carless, 2004; Littlewood, 2007). Thus, this challenge should be taken into account for the teacher in selecting materials and designing a lesson plan that can accommodate all students' English proficiency.

\section{CONCLUSION}

Based on the data analysis, this study revealed that the implementation of Task-Based Instruction contributes to students' speaking skill. The contribution was indicated by how the students actively respond to the questions, how they interact in groups, and how they perform speaking confidently. Besides, the contribution was also shown by how the students pronounce words, use appropriate vocabulary, and pay attention to grammatical form. Further, Task-Based Instruction was found enhancing students' participation in a teaching-learning process particularly when the teacher asked questions.

However, apart from those benefits, some challenges were also found in this teaching learning process through TaskBased Instruction. The challenges had something to do with teacher's competence, availability of time, and mixed ability students.

Finally, it can be concluded that the result of the study confirmed the possibility of teaching English which uses Task-Based Instruction in assisting vocational high school students to speak 


\section{Mutiara Stepani}

The Implementation of Task-Based Instruction in Teaching Speaking

English. It indicated that Task-Based Instruction can be applied in EFL vocational high school in Indonesia.

\section{REFERENCES}

Aleksandrzak, M. (2011). Problems and challenges in teaching and learning speaking at advanced level. Uniwersytet Im. Adama Mickiewicza W Poznaniu. Retrieved from http://pressto.amu.edu.pl/index.php /gl/article/download/324/231

Aliakbari, M., \& Jamalvandi, B. (2012). The impact of "Role Play" on fostering EFL learners' speaking ability: A TaskBased approach. Pan-Pacific Association of Applied Linguistics, 14(1), 15-29.

Alwasilah, A. C. (2001). Language, culture, and education: A portrait of contemporary indonesia. Bandung: $\mathrm{CV}$ Andira.

Bashir, M., Azeem, M., \& Dogar, A. H. (2011). Factor effecting students' English speaking skills. British Journal of Arts and Social Sciences, 2(1). Retrieved from http://www.bjournal.co.uk/BJASS.as $\mathrm{px}$

Beretta, A., \& Davies, A. (1985). Evaluation of the Bangalore project. Retrieved from http://doi.org/10.1093/elt/39.2.121

Branden, K. (2006). Task-based language education: From theory to practice (1st ed.). Cambridge: Cambridge University Press.

Carless, D. (2004). Issues in teachers' reinterpretation of a task-based innovation in primary schools. TESOL Quarterly. 38, 639-662. Retrieved from

http://web.edu.hku.hk/f/acadstaff/4 12/2004_Issues-in-teachers-reinterpretation-of-a-task-basedinnovation-in-primary-schools.pdf

Creswell, J. W. (2008). Research design: Qualitative, quantitative, and mixed methods approaches (3rd ed.).

Thousand Oaks, Calif: SAGE

Publications, Inc.

Ellis, R. (2003). Task-based language learning and teaching (1st ed.). Oxford: Oxford University Press.

Febriyanti, E. R. (2011). Teaching speaking of English as a foreign language:

Problems and solutions. Indonesia

Scientific Journal Database, 1(2), 133146.

Gebhard, J. G. (2009). Teaching English as a foreign or second language: A teacher self-development and methodology guide (2nd ed.). Ann Arbor: University of Michigan Press ELT.

Gunawan, I. D. (2013). Penerapan model pembelajaran berbasis tugas (TaskBased Learning) bagi peningkatan keterampilan berbicara bahasa inggris (Disertasi). Universitas Pendidikan Indonesia, Bandung. Retrieved from repository.upi.edu

Harmer, J. (2007). How to teach English. Essex: Pearson Education Limited.

Hasan, A. A. A. (2014). The effect of using task-based learning in teaching English on the oral performance of the secondary school students. International Interdisciplinary Journal of Education, 3(2), 250-264.

Hyde, C. (2013). Task-based language teaching in the business English classroom (Doctoral dissertation). University of Wisconsin, River Falls. Retrieved from https://minds.wisconsin.edu Ismaili, M. (2013). The effectiveness of the task-based learning in developing students' speaking skills in academic settings on the EFL classroom. 1st Albania International Conference on Education (AICE).

Kırkgöz, Y. (2011). A blended learning study on implementing video recorded speaking tasks in task-based classroom instruction. The Turkish 
Online Journal of Educational Technology, 10(4).

Krahnke, K. (1987). Approaches to syllabus design for foreign language teaching. Englewood Cliffs, N.J.: Center for Applied Linguistics.

Kumaravadivelu, B. (2012). TESOL methods: Changing tracks, challenging trends. Tesol Quarterly, 40(1), 59-81. http://doi.org/10.2307/40264511

Li, D. F., (1998). “It's always more difficult than you plan and imagine": Teachers' perceived difficulties in introducing the communicative approach in South Korea. TESOL Quarterly, 32, 677-703. DOI: $10.2307 / 3588000$

Littlewood, W. (2007). Communicative and task-based language teaching in East Asian classrooms. Language Teaching, 40(03), 243-249.

Lochana, M., \& Deb, G. (2006). Task-based teaching: Learning English without tears. The Asian EFL Journal Quarterly, 8(3).

Malihah, N. (2010). The effectiveness of speaking instruction through taskbased language teaching. REGISTER. 3(1), 85-101.

Merriam, S. B. (1991). Case study research in education: A qualitative approach (1 $1^{\text {st }}$ ed.). San Francisco: Jossey-Bass.

Nunan, D. (2004). Task-based language teaching. Cambridge: Cambridge University Press.

Oradee, T. (2012). Developing speaking skills using three communicative activities (discussion, problem-solving, and role-playing). International Journal of Social Science and Humanity, 2(6), 533-535. Retrieved from http://doi.org/10.7763/IJSSH.2012.V 2.164

Prabhu, N. S. (1987). Second language pedagogy. Oxford: Oxford University Press.
Richards, J. C. (2008). Teaching listening and speaking from theory to practice. Cambridge: Cambridge University Press.

Richards, J. C., \& Rodgers, T. S. (2001). Approaches and methods in language teaching (2nd ed.). Cambridge: Cambridge University Press.

Rohani, S. (2012). Oral communication strategies: Task-based learning and Indonesian EFL learners (thesis). Monash University. Retrieved from http://arrow.monash.edu.au/vital/ac cess/manager/Repository/monash:8 9359

Ruso, N. (2007). The influence of task based learning on EFL classrooms. Asian EFL Journal, 18. Retreived from http://www.asian-efljournal.com/pta_February_2007_tr.p df

Shehadeh, A., \& Coombe, C. (2010). Introduction: From theory to practice in task-based learning. In Applications of Task-Based Learning in TESOL (17). Retrieved from http://www.tesol.org/docs/defaultsource/books/bk_cp_applicationstask -based_5684.pdf?sfvrsn=4

Torky, S. (2006). The effectiveness of a taskbased instruction program in developing the English language speaking skills of secondary stage students. Ain Shams University Women's College. Retrieved from http://www.awej.org/index.php?opti on=com_content $\&$ view $=$ article $\& i d=1$ 50:shaimaa-abd-el-fattah-ibrahimtorky\&catid $=20 \&$ Itemid $=117$

Uraiwan, S. (2010). The use of task-based learning and group work incorporating to develop English ability of Mattayom Suksa 4 students. Srinakharinwirot University. Retrieved from http://thesis.swu.ac.th/swuthesis/Te a_Eng_For_Lan(M.A.)/Uraiwan_S.pdf. 


\section{Mutiara Stepani}

The Implementation of Task-Based Instruction in Teaching Speaking

Wichitwarit, N. (2014). Essential elements contributing to the success of taskbased implementation in an English classroom. Panyapiwat Journal, 5.

Willis, J. (1996). A framework for task-based learning. Harlow: Addison Wesley Publishing Company.
Xiongyong, C., \& Samuel, M. (2011).

Perceptions and implementation of task-based language teaching among secondary school EFL teachers in China. International Journal of Business and Social Science, 2(24), 292. 